\title{
5-Aminouracil and other inhibitors of DNA replication induce biphasic interphase-mitotic cells in apical root meristems of Allium cepa
}

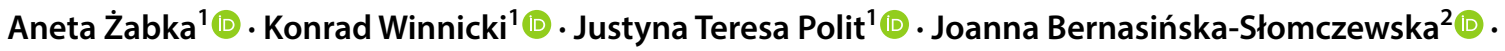 \\ Janusz Maszewski ${ }^{1}$ (D)
}

Received: 18 December 2019 / Accepted: 9 April 2020 / Published online: 23 April 2020

(c) The Author(s) 2020

\begin{abstract}
Key message Induction of biphasic interphase-mitotic cells and PCC is connected with an increased level of metabolism in root meristem cells of Allium cepa.

Abstract Previous experiments using primary roots of Allium cepa exposed to low concentrations of hydroxyurea have shown that long-term DNA replication stress (DRS) disrupts essential links of the S-M checkpoint mechanism, leading meristem cells either to premature chromosome condensation (PCC) or to a specific form of chromatin condensation, establishing biphasic organization of cell nuclei with both interphase and mitotic domains (IM cells). The present study supplements and extends these observations by describing general conditions under which both abnormal types of M-phase cells may occur. The analysis of root apical meristem (RAM) cell proliferation after prolonged mild DRS indicates that a broad spectrum of inhibitors is capable of generating PCC and IM organization of cell nuclei. These included: 5-aminouracil (5-AU, a thymine antagonist), characterized by the highest efficiency in creating cells with the IM phenotype, aphidicolin (APH), an inhibitor of DNA polymerase $\alpha, 5$-fluorodeoxyuridine (FUdR), an inhibitor of thymidylate synthetase, methotrexate (MTX), a folic acid analog that inhibits purine and pyrimidine synthesis, and cytosine arabinoside (Ara-C), which inhibits DNA replication by forming cleavage complexes with topoisomerase I. As evidenced using fluorescence-based click chemistry assays, continuous treatment of onion RAM cells with 5-AU is associated with an accelerated dynamics of the DNA replication machinery and significantly enhanced levels of transcription and translation. Furthermore, DRS conditions bring about an intensified production of hydrogen peroxide $\left(\mathrm{H}_{2} \mathrm{O}_{2}\right)$, depletion of reduced glutathione $(\mathrm{GSH})$, and some increase in DNA fragmentation, associated with only a slight increase in apoptosis-like programmed cell death events.
\end{abstract}

Keywords Allium cepa $\cdot 5$-AU $\cdot$ IM cells $\cdot$ Replication stress $\cdot$ ROS $\cdot$ Metabolic activity

\section{Abbreviations}

5-EU 5-Ethynyl uridine

AL-PCD Apoptosis-like programmed cell death

APH Aphidicolin

Ara-C Cytosine arabinoside

DAB 3,3-Diaminobenzidine tetrachloride

Communicated by Günther Hahne .

Aneta Żabka

aneta.zabka@biol.uni.lodz.pl

Konrad Winnicki

konrad.winnicki@biol.uni.lodz.pl

Justyna Teresa Polit

justyna.polit@biol.uni.lodz.pl

Joanna Bernasińska-Słomczewska

joanna.bernasinska@biol.uni.lodz.pl
dNTPs Deoxynucleotide triphosphates

DSBs Double-stranded DNA breaks

EdU 5-Ethynyl-2'-deoxyuridine

FLI Fluorescent labeling intensities

FUdR 5-Fluorodeoxyuridine

GSH Reduced glutathione

$\mathrm{H}_{2} \mathrm{O}_{2} \quad$ Hydrogen peroxide

HPG L-homopropargylglycine
Janusz Maszewski

janusz.maszewski@biol.uni.lodz.pl

1 Department of Cytophysiology, Faculty of Biology and Environmental Protection, University of Lodz, Pomorska 141/143, 90-236 Lodz, Poland

2 Department of Molecular Biophysics, Faculty of Biology and Environmental Protection, University of Lodz, Pomorska 141/143, 90-236 Lodz, Poland 


$\begin{array}{ll}\text { HU } & \text { Hydroxyurea } \\ \text { IM } & \text { Interphase-mitotic (cells, nuclei, or phenotype) } \\ \text { MTX } & \text { Methotrexate } \\ \text { PCC } & \text { Premature chromosome condensation } \\ \text { RAM } & \text { Root apical meristem } \\ \text { RFs } & \text { Replication forks } \\ \text { RNR } & \text { Ribonucleotide reductase } \\ \text { ROS } & \text { Reactive oxygen species } \\ \text { RS } & \text { Replication stress } \\ \text { SSBs } & \text { Single-stranded DNA breaks }\end{array}$

\section{Introduction}

The dynamics of plant growth and development depends largely on the mitotic activity of root and shoot apical meristems (RAMs and SAMs), which provide cells for organogenesis and tissue expansion. Hence, any biotic, abiotic, or anthropogenic stress that affects these zones may exert a destructive effect on their functional organization and consequently may negatively influence the rate of vegetation. However, in order to reproduce, plants need to keep the ability to grow irrespective of the variety of detrimental events. Therefore, the surveillance activities used by plants must somehow combine the 'stability' that preserves species-specific modes of growth and differentiation with the 'flexibility' that can overcome harmful conditions. A detailed insight into molecular processes involved in the cell cycle control systems (also known as cell cycle checkpoints) and in the adaptation to stress (developed as the survival strategy) is generally thought to be indispensable for the understanding of the mechanisms underlying stress-resistance in plants (Cools et al. 2011).

Roots are endangered by harsh water conditions, such as increased salinity, desiccation, flooding, unfavorable $\mathrm{pH}$ values, or soil polluted with heavy metals, and are usually more severely affected by exposure to multiple abiotic stresses than the aerial parts of a plant (Franco et al. 2011). Additionally, all the growth-limiting factors are also capable of inducing reactive oxygen species, (ROS; Choudhury et al. 2017) which depending on the biological context, function as important signaling molecules and, at higher levels, as sources of numerous oxidative events leading to genomic lesions and to the ensuing disintegration of nuclear DNA. Therefore, an increase in ROS is not only the first defense line to help control environmental risks, but is also the main cause of damage at the chromosomal level. Furthermore, single- and double-stranded DNA breaks (SSBs and DSBs), which are among the most genotoxic insults, can arise spontaneously due to the defects in the S-phase of the cell cycle. Exposures to all kinds of chemical or physical agents that interfere with the replication machinery may thus lead to faulty nuclear divisions, causing cells either to lose their meristematic identity and to initiate vascular differentiation, or eventually (as a result of excessive levels of DNA damage), to employ an in-built mechanism for cellular destruction via apoptosis-like programmed cell death (AL-PCD) (Cools et al. 2011; Waterworth et al. 2011). It is essential, therefore, that we have a clear understanding of how root tip cells are preserved by triggering (but also by skipping) cell cycle checkpoints, which block DNA replication and mitotic activity as long as the stress endures.

The precise control over the sequence of events in interphase and mitosis largely depends on the functions of surveillance mechanisms that recognize various types of DNA damage and act in multiple ways to maintain genome integrity. The overall role of these molecular systems is to detect DNA replication blocks, SSBs, DSBs, or abnormally structured DNA, and to slow or arrest cell cycle progression; thereby, allowing time for appropriate repair mechanisms needed to correct genetic defects before they are passed on to the next generation of cells or organisms. Cells monitor S-phase progression and respond to DNA stress by using three partially distinct, but overlapping S-phase checkpoints: (1) the replication checkpoint, activated by stalled replication forks (RFs) to prevent DNA synthesis from new initiation sites (unfired origins), (2) the intra-S-phase checkpoint, turned on by the DNA damage during S-phase, and (3) perhaps the most remarkable control pathway conserved across all eukaryotic forms of life, the S-M checkpoint, which ensures that mitosis is not initiated in cells undergoing DNA replication (Eykelenboom et al. 2013). Additionally, by slowing down or inhibiting DNA synthesis, the S-M control system ensures that only a reduced pool of deoxynucleotide triphosphates (dNTPs) is required; thus, indirectly precluding the appearance and processivity of new RFs (Segurado and Tercero 2009; Cools et al. 2011). Failure of the S-M checkpoint leads to mitotic catastrophe of cells with incompletely replicated DNA (Stauffer et al. 2007).

There is a variety of well-known conditions or obstacles, which may result in slowing down or stalling of RFs progression, both referred to as the replication stress (RS). These comprise DNA nicks and gaps, stretches of singlestranded DNA (ssDNA), unrepaired DNA lesions, misincorporation of ribonucleotide triphosphates (rNTP), unusual DNA structures (e.g., hairpins, triplexes), dormant replication origins and many other cis and trans molecular barriers, including early-replicating and common fragile sites (ERFSs and CFSs), repetitive DNA elements, and collisions between the replication and transcription complexes (Magdalou et al. 2014; Mazouzi et al. 2014; Zeman and Cimprich 2014; Gelot et al. 2015; Berti and Vindigni 2016). Moreover, the list of RS-inducing factors has to be extended by the insufficient levels of proteins (such as histones and histone chaperones) and/or dNTPs. All these events can induce a set of cellular reactions, known as DNA damage response (DDR), which 
form a complex signaling network consisting of cell cycle checkpoints, DNA-repair mechanisms, and DNA damage tolerance pathways (Giglia-Mari et al. 2011).

The response of plant cells to RS is largely unexplored. Among many tools available to facilitate experimental studies on this subject, the most widely employed; thus far, was the use of hydroxyurea (HU), an inhibitor of ribonucleotide reductase (RNR). HU reduces the pool of dNTPs and affects replication fork progression (Saban and Bujak 2009). A number of side effects associated with HU-mediated inhibition of RNR comprise dissociation of the replication complex, accumulation of hemi-replicated intermediates, ssDNA interruptions at stalled RFs (which may then become converted into DSBs), formation of Holliday junctions through fork reversal, and other types of DNA damage, including those induced by ROS. Our previous studies focused on the effects of RS in onion (Allium cepa) primary root meristems exposed to low doses of $\mathrm{HU}$ clearly showed a definite interruption of the S-M checkpoint functions, leading cells either to premature chromosome condensation (PCC), or to an abnormal organization of chromatin, with both interphase (I) and mitotic (M) domains formed simultaneously on the opposing poles of the nuclei (IM cells; Żabka et al. 2010, 2012, 2013, 2015a, b). Consequently, our observations were the first to demonstrate a novel means by which interphase chromatin may become gradually compacted into mitotic chromosomes, creating large-scale compartments capable to perform independent functions relevant to their specific organizational designs. Furthermore, the recent screening studies suggest that the biphasic nuclear IM phenotype may also be induced in other crop species, e.g., sunflower (Helianthus annuиs) and Legumes, such as broad bean (Vicia faba) and lentil (Lens culinaris; Żabka et al., in prep.).

In the present study, using Allium cepa root meristem model, we have shown that many inhibitors of DNA replication, when applied at low concentrations, may generate both PCC-like and biphasic IM cells similar to those formed under the prolonged (3-day) influence of HU. This type of response to the replication stress induced by 5 -aminouracil (5-AU; selected for most of our further studies because of its highest efficiency in creating cells with the IM phenotype) has been found correlated with their significantly increased production of hydrogen peroxide $\left(\mathrm{H}_{2} \mathrm{O}_{2}\right)$, depletion of reduced glutathione (GSH) and the enhanced levels of DNA synthesis, transcription and translation.

\section{Materials and methods}

\section{Plant material}

Calcium hypochlorite sterilized seeds of Allium cepa L. (obtained in 2018 from the agriculture farm "Lubiczow") were sown on wet paper sheets in covered Petri dishes and germinated in the dark at $20{ }^{\circ} \mathrm{C}$ for 4 days. Seedlings with primary roots reaching $1.5 \pm 0.2 \mathrm{~cm}$ were cultivated on blotting paper in trays filled with $10 \mathrm{~mL}$ of either distilled water (control samples) or chosen solutions of 5-aminouracil (5-AU; $750 \mu \mathrm{M}$ ) for 1, 3, 6, 12, 24, 48, and $72 \mathrm{~h}$, and aphidicolin (APH; $750 \mu \mathrm{M}$ ), cytosine arabinoside (Ara$\mathrm{C} ; 100 \mu \mathrm{M})$, 5-fluorodeoxyuridine (FUdR; $0.74 \mu \mathrm{M})$, and methotrexate (MTX; $0.25 \mu \mathrm{M}$ ) for $72 \mathrm{~h}$, at $20^{\circ} \mathrm{C}$ in the dark.

\section{Feulgen staining}

Excised roots were fixed in ice-cold Carnoy's solution (absolute ethanol and glacial acetic acid; 3:1, v/v) for $1 \mathrm{~h}$, washed several times with ethanol and, after rehydration, hydrolyzed in $4 \mathrm{M} \mathrm{HCl}(1 \mathrm{~h})$. The staining procedure with Schiff's reagent (pararosaniline) was performed according to the standard method (e.g., Polit et al. 2002). After rinsing in $\mathrm{SO}_{2}$-water (3 times) and distilled water, intensely stained apical segments (1.0-1.5 mm long) were cutoff, placed in $45 \%$ acetic acid and squashed onto Super-Frost microscope slides. Following freezing (dry ice), coverslips were removed, and the dehydrated slides were mounted in Canada balsam.

\section{EdU labeling and visualization of DNA replication on individual chromatin fibers}

Onion seedlings were incubated with $10 \mu \mathrm{M}$ 5-ethynyl-2'deoxyuridine (EdU; Thermo Fisher Scientific) and 5-AU for $20 \mathrm{~min}$, in the dark. Excised root tips were fixed in PBSbuffered $4 \%$ paraformaldehyde $\left(4^{\circ} \mathrm{C} ; \mathrm{pH} 7.4\right)$ for $40 \mathrm{~min}$, and macerated for 15 min with citrate-buffered $2.5 \%$ pectinase from Aspergillus niger (Sigma), at $\mathrm{pH}$ 5.0. Meristems were squashed onto microscope slides (Polysine ${ }^{\mathrm{TM}}$, MenzelGläser) and air dried. After washing with PBS, DNA replication in nuclei were visualized using Click-iT DNA Alexa Fluor $^{\circledR} 555$ Imaging Kit (Thermo Fisher Scientific), according to the supplier's instructions. Slides were washed with PBS and stained with $15 \mu \mathrm{M}$ 4',6-diamidino-2-phenylindole (DAPI; Sigma-Aldrich) for $15 \mathrm{~min}$, and, after washing with PBS, mounted in PBS/glycerol/DABCO mixture.

For visualization of DNA replication on individual chromatin fibers, onion root tips were incubated in EdU solution as described previously, fixed in Tris-buffered $1 \%$ formalin $\left(4^{\circ} \mathrm{C} ; \mathrm{pH}\right.$ 7.2), and washed with ice-cold TRIS-HCl. Cell nuclei were isolated according to Van't Hof (1980) by squeezing the meristems in a drop of PBS between two microscope slides, mixed with lysis buffer $(0.5 \%$ sodium dodecyl sulfate, $50 \mathrm{mM}$ EDTA, $200 \mathrm{mM}$ Tris, $\mathrm{pH}$ 7.4), incubated at room temperature for $10 \mathrm{~min}$ and transferred onto the surface of coverslips silanized according to the modified protocol of Labit et al. (2008). The drop of extracted nuclear 
DNA was allowed to flow downwards by gravity and dried coverslips were processed for single staining using ClickiT $^{\circledR}$ EdU Alexa Fluor ${ }^{\circledR} 555$ reaction cocktail (Thermo Fisher Scientific) consisting of components prepared according to the vendor's manual. Incubation was performed at $25{ }^{\circ} \mathrm{C}$ for $60 \mathrm{~min}$. Slides were mounted in PBS/glycerol/DABCO mixture.

\section{5-Ethynyl uridine incorporation and detection of nascent RNA}

Control and 5-AU-treated onion seedlings were incubated for $1 \mathrm{~h}$ with $1 \mathrm{mM}$ solution containing 5-ethynyl uridine (5-EU; Thermo Fisher Scientific), respectively with or without 5-AU, in the dark. Then, excised 1.5-mm-long root tips were fixed in PBS-buffered $4 \%$ paraformaldehyde $\left(4{ }^{\circ} \mathrm{C}\right.$; $\mathrm{pH}$ 7.4) for $40 \mathrm{~min}$, washed with PBS and macerated for 45 min with the citrate-buffered $2.5 \%$ pectinase ( $\mathrm{pH} 5.0$; $40{ }^{\circ} \mathrm{C}$ ). After rinsing with cold PBS, root meristems were squashed onto microscope slides (Polysine ${ }^{\mathrm{TM}}$, MenzelGläser) in a drop of distilled water. Following freezing with dry ice, coverslips were removed, slides were washed with PBS, distilled water, and air dried. Macerated cells were then permeabilized with $0.5 \%$ Triton X-100 for $15 \mathrm{~min}$. Nascent RNA was visualized using Click-iT ${ }^{\circledR}$ RNA Alexa Fluor $^{\circledR} 488$ Imaging Kit with the reaction cocktail (Thermo Fisher Scientific). After $1 \mathrm{~h}$ incubation at room temperature, slides were washed in Click-iT ${ }^{\circledR}$ reaction rinse buffer and PBS, counterstained for 1 min with propidium iodide (PI; $0.3 \mathrm{mg} \mathrm{mL}^{-1}$ ) and washed in PBS. Specimens were mounted in PBS/glycerol/DABCO mixture.

\section{Protein synthesis assay}

Nascent protein synthesis was detected using Click-iT ${ }^{\circledR}$ HPG Alexa Fluor ${ }^{\circledR} 488$ Protein Synthesis Assay Kit (Thermo Fisher Scientific). Root fragments ( $1.5 \mathrm{~cm}$ long) cut off from the control, 5-AU-treated, and $50 \mu \mathrm{M}$ cycloheximide-treated onion seedlings were transferred to $50 \mu \mathrm{M}$ water solution of L-homopropargylglycine (HPG; control) or to the mixture of $\mathrm{HPG}+5$-AU or HPG + cycloheximide, in dark. After $30 \mathrm{~min}$, apical root parts were fixed in phosphate-buffered saline (PBS)-buffered $3.7 \%$ paraformaldehyde $\left(4{ }^{\circ} \mathrm{C} ; \mathrm{pH}\right.$ 7.4) for $45 \mathrm{~min}$. For maceration, excised meristems were rinsed twice in PBS and transferred for 45 min to the citratebuffered $2.5 \%$ pectinase. Next, root tips were squashed onto microscope slides (Polysine ${ }^{\mathrm{TM}}$, Menzel-Gläser) in a drop of distilled water, and placed on dry ice. After 15 min, coverslips were removed, and the slides were washed with PBS, distilled water, and air dried. Permeabilization of macerated cells was performed using $0.5 \%$ Triton X-100 for 15 min. HPG incorporation was detected using Click-i ${ }^{\circledR}$ reaction cocktail consisting of components prepared according to the vendor's manual. Incubation was performed at room temperature for $30 \mathrm{~min}$ and, after that slides were washed in Click$\mathrm{iT} \circledast$ reaction rinse buffer and PBS. Cell nuclei were stained for 5 min with DAPI at a concentration of $0.4 \mathrm{mg} \mathrm{mL}^{-1}$, washed in PBS and mounted in PBS/glycerol/DABCO mixture.

\section{Detection of $\mathrm{H}_{2} \mathrm{O}_{2}$}

The generation of $\mathrm{H}_{2} \mathrm{O}_{2}$ was observed following treatment with 3,3-diaminobenzidine tetrachloride (DAB; SigmaAldrich) according to Thordal-Christensen et al. (1997), with minor modifications. Prior to fixation, control and 5-AU-treated onion seedlings were plunged in Tris-buffered ( $10 \mathrm{mM}$ Tris, $10 \mathrm{mM} \mathrm{Na}{ }_{2}$ EDTA, $100 \mathrm{mM} \mathrm{NaCl}$ ) DAB $(1 \mathrm{mg} / \mathrm{mL} ; \mathrm{pH} 7.5)$ dissolved in distilled water (control) or 5 -AU for $8 \mathrm{~h}$. Excised root tips were fixed for $45 \min \left(20^{\circ} \mathrm{C}\right)$ in PBS-buffered $3.7 \%$ paraformaldehyde, washed several times with PBS, and placed in citrate-buffered $2.5 \%$ pectinase ( $\mathrm{pH} 5.0,37^{\circ} \mathrm{C}$ for $45 \mathrm{~min}$ ). Digested root meristems were washed with PBS and squashed onto microscope slides in a mixture of glycerol and PBS $(9: 1 ; \mathrm{v} / \mathrm{v})$. Generated $\mathrm{H}_{2} \mathrm{O}_{2}$ was visualized under the microscope as a reddish-brown coloration of the cells (DAB reacts with $\mathrm{H}_{2} \mathrm{O}_{2}$ in the presence of peroxidase, forming a brown polymerized product).

\section{Detection of AL-PCD by TUNEL assay}

For the terminal deoxynucleotidyl transferase dUTP nick end labeling staining (TUNEL assay), root meristems were fixed in PBS-buffered 4\% paraformaldehyde for $20 \mathrm{~min}$ at $4{ }^{\circ} \mathrm{C}$ and stained using the in situ cell death detection kit (Click-iT ${ }^{\circledR}$ TUNEL Alexa Fluor ${ }^{\circledR} 488$ Imaging Assay; Thermo Fisher Scientific) according to manufacturer's instructions. Negative control was performed without the terminal deoxynucleotidyl transferase (TdT) and a positive control was performed with DNase I. Cell nuclei were stained with DAPI (as before) and mounted in a mixture of glycerol and PBS $(9: 1 ; \mathrm{v} / \mathrm{v})$.

\section{Detection of glutathione using ThiolTracker ${ }^{\mathrm{Tm}}$ Violet}

Onion seedlings were incubated for 30 min with $20 \mu \mathrm{m}$ ThiolTracker ${ }^{\mathrm{TM}}$ Violet (Thermo Fisher Scientific) dissolved in DPBS with C/M (Dulbecco's phosphate buffered saline, containing $\mathrm{Ca}++$ and $\mathrm{Mg}++$, glucose, and sodium pyruvate; Thermo Fisher Scientific). After washing with DPBS $\mathrm{C} / \mathrm{M}$, hand-made longitudinal sections of root meristems and RAM cells squeezed onto microscopic slides were counterstained with Hoechst 33342 dye (Sigma-Aldrich), mounted in a mixture of glycerol and PBS (9:1; v/v) and observed using a fluorescence microscope. 


\section{DNA fragmentation assay by agarose gel electrophoresis}

Total DNA was extracted and purified from excised onion root meristems grown in water (control) and treated with 5-AU for 72-h using the MagMAX ${ }^{\text {TM }}$ Plant DNA Kit (Thermo Fisher Scientific). According to the procedure used earlier (Żabka et al. 2016), samples containing $10 \mu$ of DNA and $2 \mu \mathrm{l}$ of gel loading buffer $(0.25 \%$ bromophenol blue, $30 \%$ glycerol in $1 \times$ TAE composed of $40 \mathrm{mM}$ Tris $-\mathrm{HCl}$, $1 \mathrm{mM}$ EDTA, $40 \mathrm{mM}$ acetic acid, $\mathrm{pH}$ 8.0) were applied to $1 \%$ agarose gel in $1 \times$ TAE buffer supplied with $1 \mathrm{mg} / \mathrm{ml}$ of ethidium bromide and separated by electrophoresis at $100 \mathrm{~V}$ for $3 \mathrm{~h}$ at room temperature. UV-fluorescent DNA fragments were photographed using a Gel UV Slider (Phoretix 1D image store system; Phoretix, England) in the Laboratory of Microscopic Imaging and Specialized Biological Techniques at the Faculty of Biology and Environmental Protection (University of Lodz).

\section{Microscopic measurements, observations, and analyses}

Observations were made using E-600 epifluorescence microscope (Nikon) equipped with phase-contrast optics, U2 filter (UVB light; $\lambda=340-380 \mathrm{~nm}$ ) for DAPI and Hoechst 33342, B2 filter (blue light; $\lambda=465-496 \mathrm{~nm}$ ) for Alexa Fluor ${ }^{\circledR} 488$, or G2 filter (green light; $\lambda=540 / 25 \mathrm{~nm}$ ) for Alexa Fluor ${ }^{\circledR}$ 555 and PI-stained cell nuclei. All images were recorded at exactly the same time of integration using a DS-Fil CCD camera (Nikon). Quantitative analyses and nuclear DNA fluorescence measurements were made after converting color images into greyscale and expressed in arbitrary units as mean pixel value (pv) spanning the range from 0 (dark) to 255 (white) according to described methods (Żabka et al. 2010, 2012). The obtained data were expressed as the mean values \pm standard deviation of the mean (SD). Student's $t$ tests for paired data were used to compare individual variables.

\section{Results}

\section{Various inhibitors of DNA replication affect mitosis and induce biphasic IM nuclei in onion RAM cells}

Considering the recognized effects of $\mathrm{HU}$ and its capacity to promote IM cells in onion root meristems (Żabka et al. 2010, 2012), our experiments were primarily aimed at establishing the extent to which similar outcomes may be produced by other drugs known to affect different aspects of DNA synthesis. As shown in Table 1, a spectrum of inhibitors efficient in generating biphasic (IM) organization of cell nuclei (tested over a broad range of dilutions) included: 5-aminouracil (5-AU), a thymine antagonist that blocks DNA synthesis and binds as a third strand capable of forming triplex DNA structures through Hoogsteen hydrogen bonds (Shaker et al. 2016), aphidicolin (APH), an inhibitor of DNA polymerase $\alpha$ (Yokoyama et al. 2016), 5-fluorodeoxyuridine (FUdR), an inhibitor of thymidylate synthetase (Anderson et al. 2016), methotrexate (MTX), a folic acid analog that inhibits purine and pyrimidine synthesis (Cutolo et al. 2001), and cytosine arabinoside (Ara-C), which incorporates into DNA and inhibits DNA replication by forming cleavage complexes

Table 1 Maximum mean number of biphasic (IM) cell nuclei per root meristem (enframed), mitotic index (MI), and percent of aberrant mitotic divisions (A) in onion RAMs after 72-h treatment with selected inhibitors, tested over a range of dilutions $(\mu \mathrm{M})$

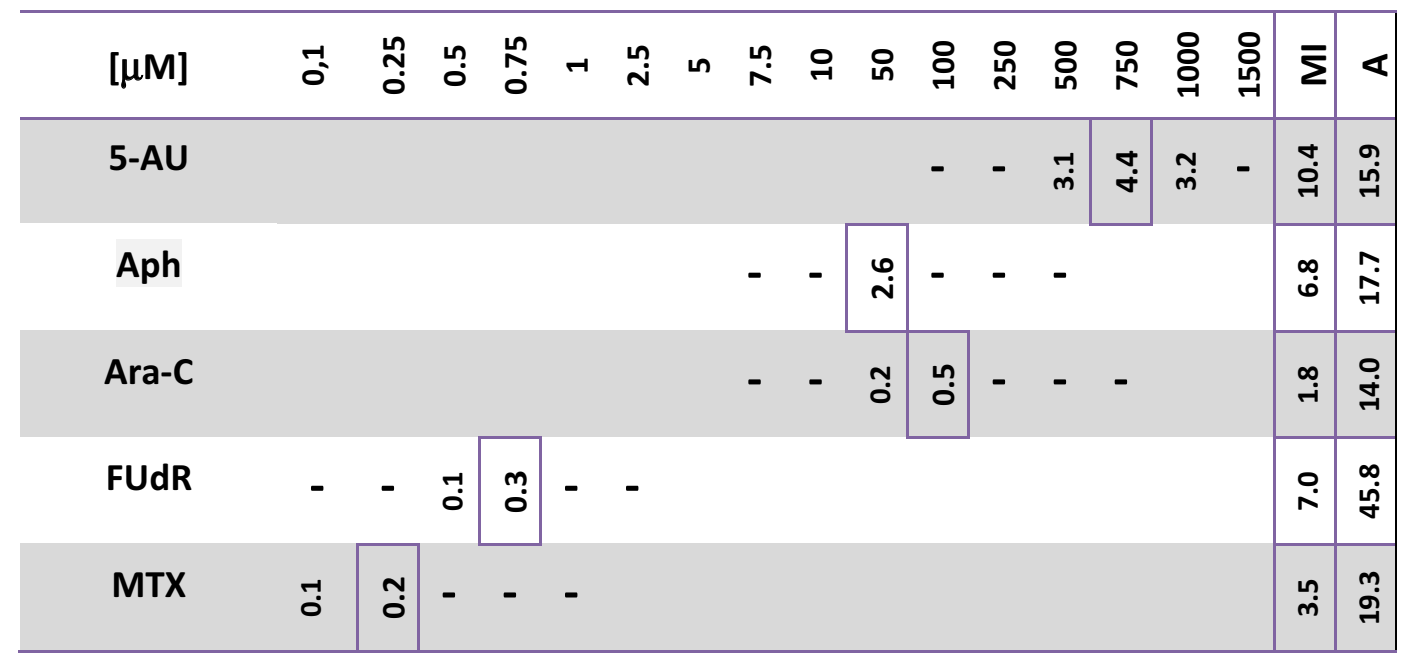

5-AU - 5-aminouracil; APH - aphidicolin, Ara-C - cytosine arabinoside, FUdR - 5-fluorodeoxyuridine, MTX - methotrexate

5-AU 5-aminouracil, $A P H$ aphidicolin, Ara-C cytosine arabinoside, $F U d R$ 5-fluorodeoxyuridine, MTX methotrexate. 
with topoisomerase I (Wang et al. 2010). No induction of IM cells was detected in experimental series using excess of thymidine or 5-FU.

Following 3-day mild treatments with 5-AU, APH, FUdR, MTX, and Ara-C, the morphological signatures of onion root apex meristem (RAM) cells were strongly consistent with those observed after the prolonged incubations using low concentrations of HU (Żabka et al 2010, 2012). All inhibitors produced a remarkable diversity of cells, with a dominant interphase fraction (visually normal) and a smaller population of mitotic cells displaying either unusual biphasic nuclear structures (IM cells; Fig. 1A) or evident symptoms of premature chromosome condensation (PCC-cells; Fig. 1B). In accordance with our earlier data (Żabka et al. 2012; 2015a), cell size seems to constitute one the major parameters determining either one or the other of the two abnormal types of nuclear division. The IM cell nuclei (also termed as "octopus-like" for their chromosomal arms sticking out of the interphase nuclear bodies) are restricted merely to a group to extremely long cells with major to minor axis ratios exceeding a factor of 3.0, whereas the PCC-like phenotype is confined to a group of M-phase cells approaching the maximum length to width ratio less than 2.5. A variety of gradients of chromatin condensation observed in the IM cell nuclei extended from interphase to early stages of prophase (Fig. $1 \mathrm{~A} \mathrm{~d}, \mathrm{j}$ ), from interphase to late stages of prophase (Fig. 1A a, b, f, g, i), or from early to late stages of prophase (Fig. 1A e, h, k). In 5-AU-treated root meristems, some cells became extremely long with correspondingly elongated and bizarrely amitosis-like arranged IM nuclei (Fig. 1A c).

Despite no evident impact on the DNA cell cycle profiles (not shown) and a varied effect on the mitotic indices (ranging from an increase after incubation with 5-AU

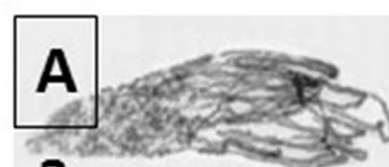

a
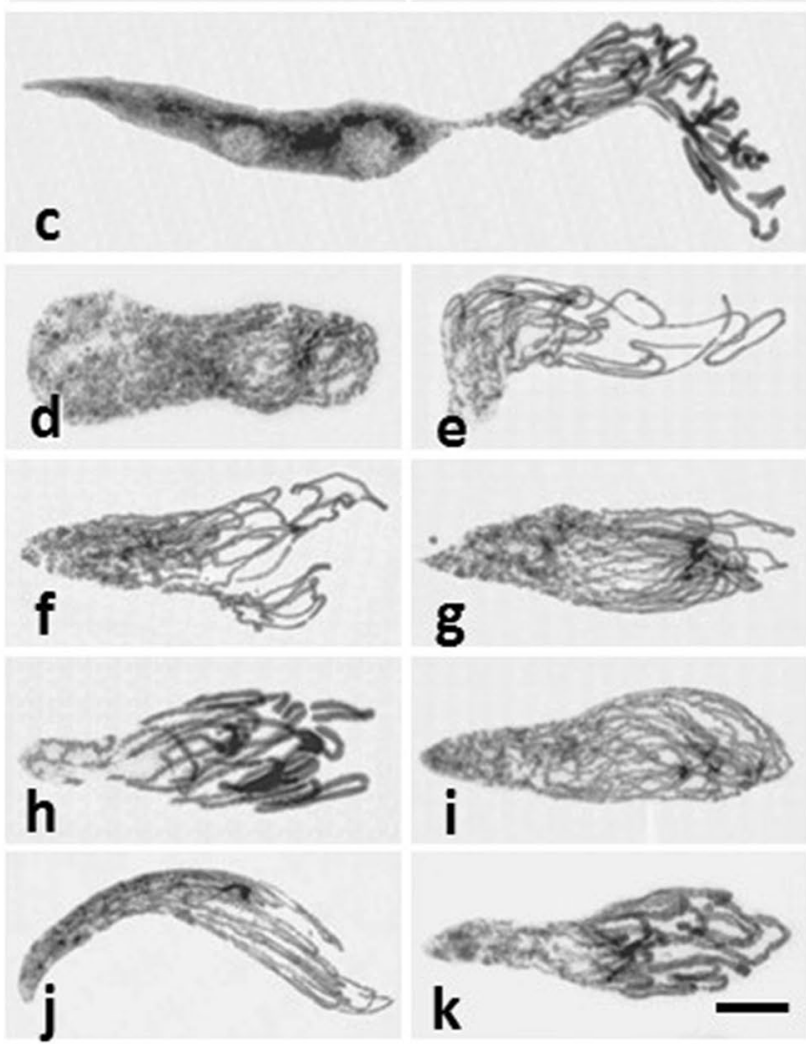

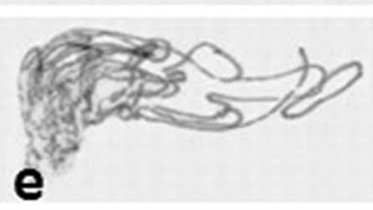

e
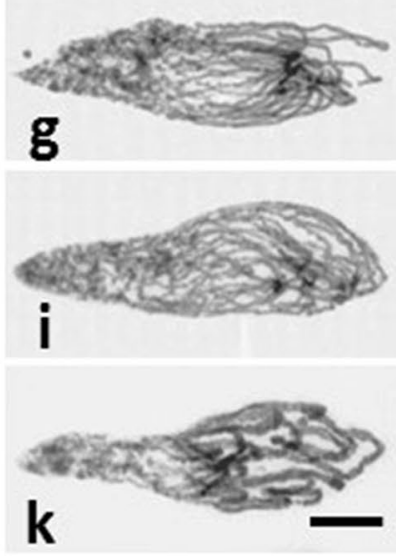

Fig. 1 Nuclear Feulgen staining of aberrant mitotic cells in A. cepa RAMs. Scale bars $=20 \mu \mathrm{m}$. A A variety of biphasic IM cells formed after $72 \mathrm{~h}$ treatment with 5-AU (a-c); note the IM cell nucleus combining biphasic and amitotic phenotype (c), APH (d, e), Ara-C (f, g), FUdR (h, i), and MTX (j, k). B Selected cell nuclei with evident
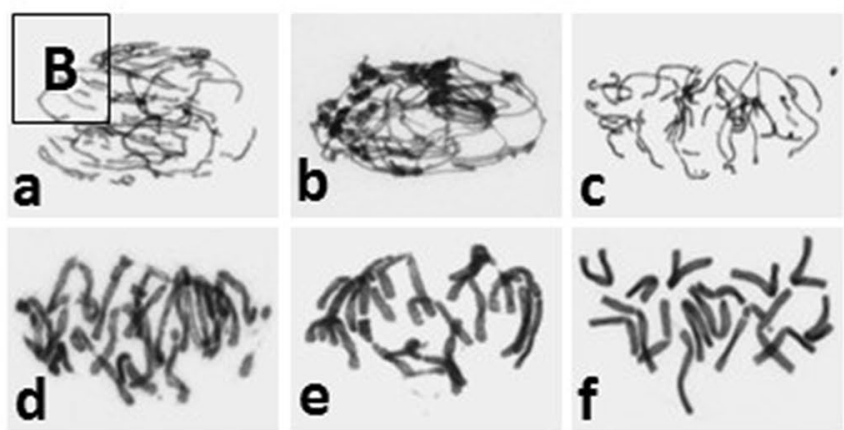

C
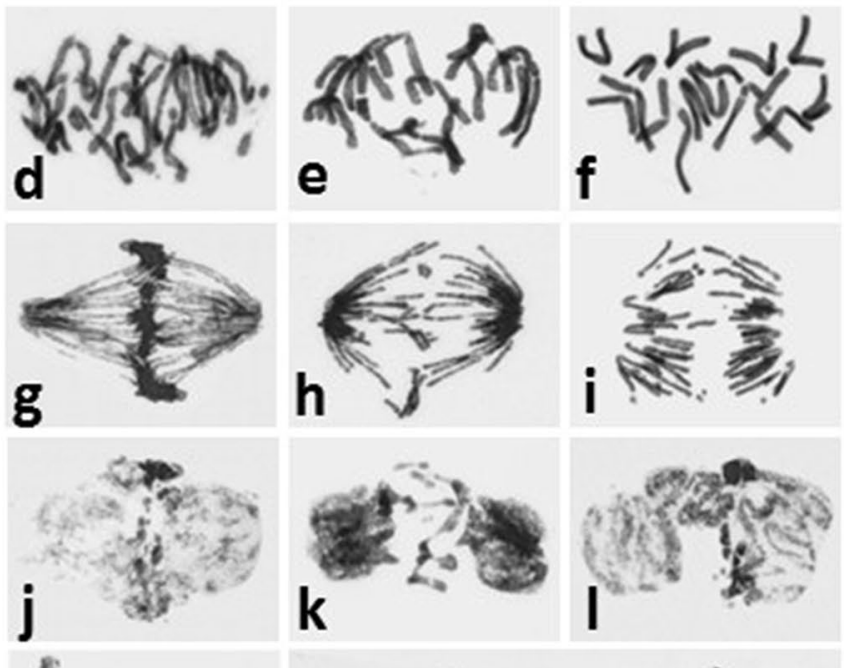

i
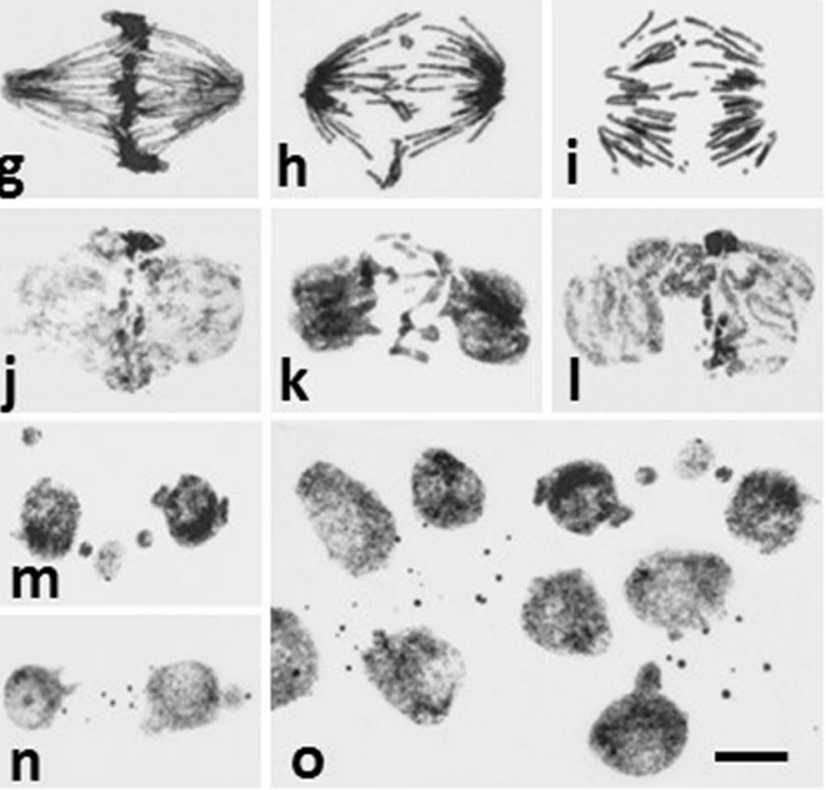

PCC-like morphology during prophase $(\mathbf{a}-\mathbf{c})$, metaphase $(\mathbf{d}-\mathbf{f})$, anaphase $(\mathbf{g}-\mathbf{i})$ and telophase $(\mathbf{j}-\mathbf{l})$ following treatment with 5-AU (a, $\mathbf{d}, \mathbf{g}, \mathbf{j}$ ), Ara-C (b, e, h, k), and MTX (c, f, i, l). Post-telophase cell nuclei with micronuclei formed after treatment with APH (m) and FUdR (n). Numerous micronuclei in 5-AU-treated RAM cells (o) 
to a considerable decrease in plants exposed to Ara-C; Table 1), all treatments resulted in a significant rise in various types of chromosome disorders (Fig. 1B) and a substantial reduction in onion RAM size (illustrated by Fig. 2a, b, following incubations with 5-AU). In addition to entangled chromosomes in prophase (Fig. 1B a-c), only a relatively small fraction of metaphase cells (about 9\%) revealed chromosomal gaps, breaks, and an abnormal arrangement of chromosomes in the equatorial plane of the cell (Fig. 1B d-f). Most frequently, structural aberrations (such as acentric fragments of chromosomes and chromosomal bridges) were observed in ana- (Fig. 1B $\mathrm{g}-\mathrm{i}$ ) and telophase cells (Fig. 1B j-1). In consequence, the 3-day incubation with each of the inhibitors enhanced the frequency of micronuclei (Fig. 1B m-o), with their most significant accumulation in 5-AU-treated roots (up to $240.7 \pm 16.2$, compared with $17.1 \pm 4.3$ in the control plants, both values per 1000 cells).

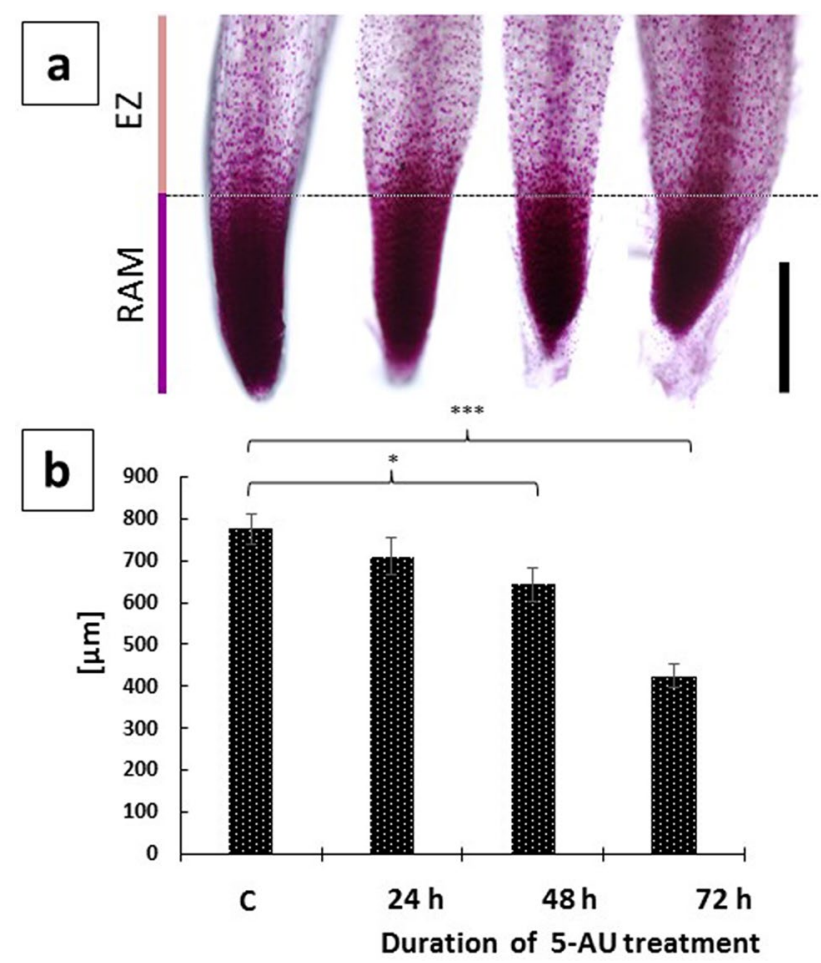

Fig. 2 Root meristem shortening during continuous incubation of $A$. cepa seedlings with 5-AU. Feulgen-stained root tips aligned according to the transition regions between RAMs and elongation zones (EZ), demarcated by dotted line (a); corresponding RAM lengths $[\mu \mathrm{m}]$ in control plants (c) and after 24, 48, and $72 \mathrm{~h}$ treatment periods (b). Scale bar $=500 \mu \mathrm{m}$. When compared with the control, statistically significant changes in mean RAM length $( \pm$ SD) are marked by asterisks: * indicates $p<0.05$ and $* * *$ indicates 0.001

\section{Incorporation of EdU into nuclear DNA during 5-AU-induced replication stress}

The thymidine nucleoside analog 5-ethynyl-2'-deoxyuridine (EdU) was applied for the recognition of S-phase cell nuclei in both control and 5-AU-treated onion RAMs after successive 1-, 3-, 6-, 12-, 24-, 48-, and 72-h incubation periods (Fig. 3). Using this method, detection of DNA synthesis relies on the $\mathrm{Cu}^{+2}$-mediated covalent reaction between an alkyne of EdU and an Alexa Fluor ${ }^{\circledR} 488$ azide (Fig. 3A). The proportions of EdU-labeled (actively replicating) to EdU-unlabeled (non-replicating) cell nuclei are exemplified by fluorescence microscopy images taken from the control (Fig. 3Ba, a') and 5-AU-treated RAM cell populations (after 1 and $72 \mathrm{~h}$ incubation periods, shown in Fig. 3Bb, b' and Fig. 3Bc, c', respectively), and quantified as labeling indices in Fig. 3E. When compared with the control root cells, after the first 1-h treatment with 5-AU, a slight decrease in EdUlabeled cells was noted. Then (starting from the $3 \mathrm{~h}$ time point), the number of replicating cells increased, reaching the highest value (69\%) at the $12 \mathrm{~h}$ time point. Beginning from the 24-h treatment, population of EdU-labeled cells gradually decreased to about $52 \%$ (72-h incubation period; Fig. 3E).

In order to evaluate the time-dependent changes in the dynamics of DNA replication, a similar set of data was collected in the sequential periods of 5-AU treatment by measuring EdU fluorescent labeling intensities, calculated as a percent of the maximum possible brightness (pixel value), represented on a grayscale range from 0 (black $=0 \%)$ to 255 (white $=100 \%$; Fig. 3E). Considering natural variation in the amount of emitted fluorescence and in their spatial distribution patterns across chromatin at different stages of the S-phase (Fig. 3C), onion RAM cells were selected with respect to DNA C values corresponding to the middle S-phase ranging from 2.8 to $3.2 \mathrm{C}$ (where $\mathrm{C}$ is the amount of DNA in the unreplicated haploid genome). In consequence, at each time point of the study, the nuclei chosen for analysis were characterized by the strongest and most homogenous EdU labeling density (Fig. 3Cc).

When compared with the intensities of fluorescence estimated for the control mid-S-phase cell nuclei (Fig. 3Ba), the relevant data scored at the earliest measurement time points throughout continuous incubation with 5-AU (after $1 \mathrm{~h}$, and significantly, after $3 \mathrm{~h}$ ) were markedly lower (Fig. 3Bb, E). At subsequent periods (6 to $24 \mathrm{~h}$ ), the dynamics of DNA replication increased considerably, reaching still higher values of fluorescence intensity to the maximum levels at 48 (Fig. 3Bc) and $72 \mathrm{~h}$ of treatment. An extremely strong EdU fluorescence signal emitted by mid-S-phase chromatin from 5-AU-treated onion RAM cell nuclei has enabled us to visualize an ongoing process of replication at a single DNA molecule level. As shown in Fig. 3D, owing 


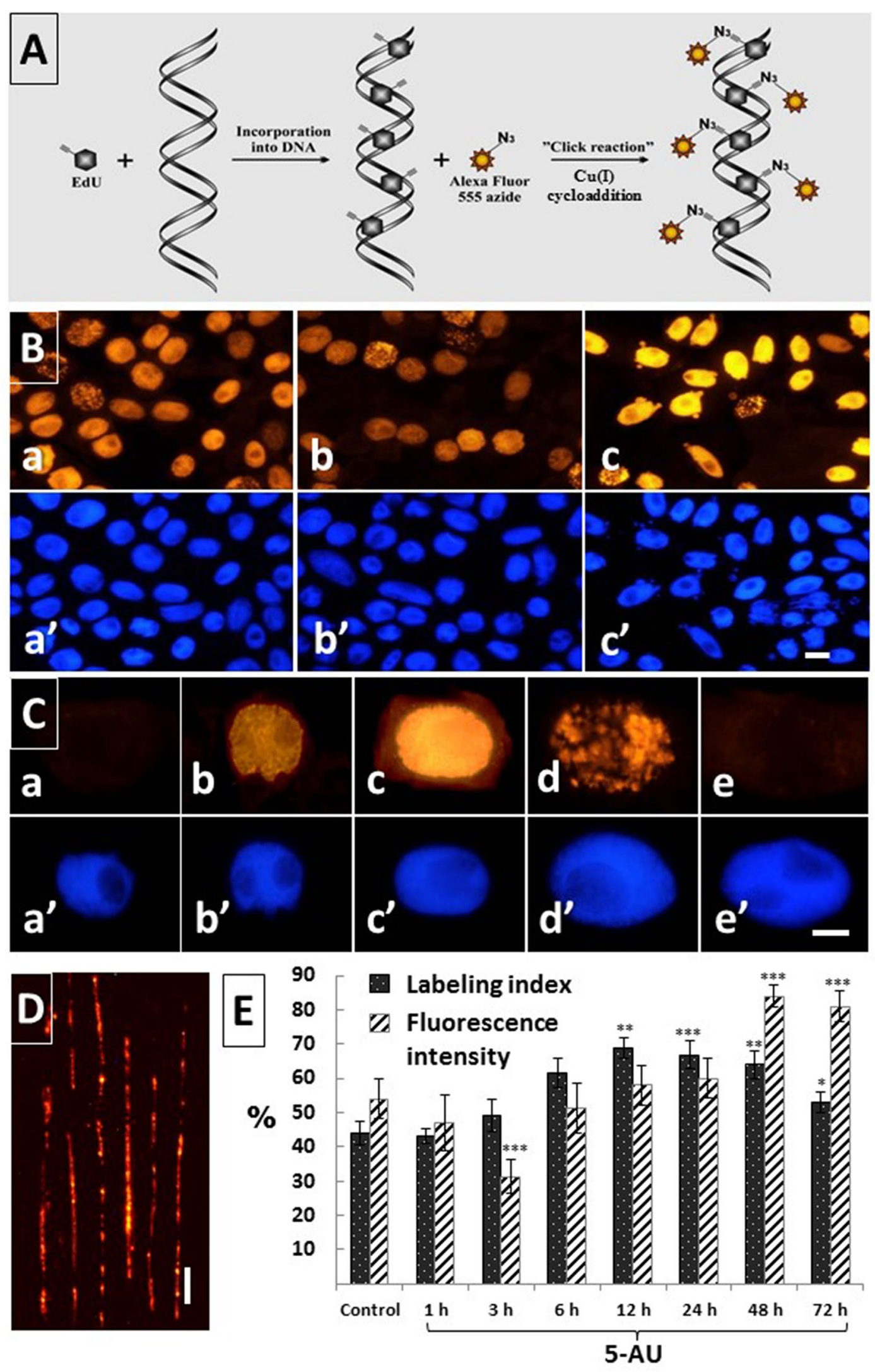


4 Fig. 3 Analysis of DNA replication in A. cepa RAMs by EdU incorporation. A Schematic representation of copper(1)-catalyzed Alexa Fluor $^{\circledR} 555$ azide-alkyne "click" reaction used to detect replicating DNA. B RAM cell populations labeled with EdU (a-c) and the same cells counterstained with DAPI $(\mathbf{a}-\mathbf{c})$ in the control seedlings (a, a), after $1 \mathrm{~h}(\mathbf{b}, \mathbf{b})$ and $48 \mathrm{~h}(\mathbf{c}, \mathbf{c})$ incubations with 5-AU. Scale bar $=20 \mu \mathrm{m}$. (C) EdU labeling of RAM cells at successive stages of interphase: G1 (a), early S (b), middle S (c), late S (d), G2 (e), with corresponding images of the same cells counterstained with DAPI (a-e). Scale bar $=10 \mu \mathrm{m}$. D Single molecule DNA fibers isolated from actively replicating cell nuclei after their $48 \mathrm{~h}$ treatment with 5-AU. Scale bar $=10 \mu \mathrm{m} \approx 20 \mathrm{kbp}$. E Mean percentage $( \pm \mathrm{SD})$ of EdU-labeled cells (labeling index; dotted diagram) and mean $( \pm S D)$ intensity of EdU labeling (Fluorescence intensity, lined diagram), calculated as a percentage of the maximum possible brightness (pixel value $=255$ ) evaluated for selected groups of mid-S-phase cell nuclei (determined microfluorimetrically following DAPI staining). The data represent values obtained for the control and 5-AU-treated onion RAM cell nuclei at successive periods of incubation. When compared with the control, statistically significant changes in mean values $( \pm \mathrm{SD})$ are marked by asterisks: * indicates $p<0.05, * *$ indicates $p<0.01$, and $* * *$ indicates $p<0.001$

to a high-fluorescence quantum yield, a simplified version of molecular combing technique using silane-coated glass slides provides both determination of origin density along the DNA and good separation of its fibers. To our best knowledge, positive results in experiments using EdUlabeled plant S-phase nuclei to demonstrate micropatterning along stretched and aligned DNA molecules has never been reported before in literature.

\section{5-AU-induced changes in the dynamics of transcription and translation}

Total transcriptional and translational activities were evaluated both in the control and 5-AU-treated RAM cells of $A$. cepa by using "click" chemistry technique and fluorometric measurements. The first assay, performed by incorporating the alkyne-modified uridine analog 5-ethynyl uridine (EU; Fig. 4), allows for a rapid detection of newly formed transcripts generated by RNA polymerases without the need of using radioactive precursors or antibodies. In general, the highest EU signals were observed in the nucleoli, which is attributed to an intense ribosomal RNA synthesis (Fig. 4Aa, b, Ca, b). When compared with the control RAM cells (Fig. 4Aa), incubation with 5-AU caused a considerable enlargement of the nucleoli (Fig. 4Ab) and about 40 per cent increase in the fluorescence intensity, noticed both in the nucleoplasmic and in the nucleolar regions (Fig. 4Ab, D). No significant differences in weak EU staining were observed between successive stages of mitosis in the untreated seedlings (Fig. 4B), whereas in the elongated prophase cells formed after the prolonged (72 h) 5-AU treatment, a significant fluorescence of RNA could be detected around and between the condensing chromosomes (Fig. 4C).
A similar reaction with L-homopropargylglycine (HPG), an amino acid analog of methionine, was used to determine an overall intensity of protein synthesis (Fig. 5A). The fluorescence measurements shown in Fig. 5B indicate that when compared with the control root cells (Fig. 5Aa, a), the translational activity of RAM cells significantly increases (by about 2.5 times) after $72 \mathrm{~h}$ treatment with 5-AU (Fig. 5Ab, b). No detectable HPG staining could be noticed in cells exposed to cycloheximide (a translation inhibitor in Eukaryotes), used as a specific negative control (Fig. 5Ac, c).

\section{5-AU-induced $\mathrm{H}_{2} \mathrm{O}_{2}$ production, decrease in the reduced glutathione (GSH) level and induction DNA damage}

Four types of analysis have been used to describe the damaging influence of prolonged $(72 \mathrm{~h})$ treatment with 5 -AU on onion RAM cells (Fig. 6): (1) microcolorimetric evaluation of the hydrogen peroxide $\left(\mathrm{H}_{2} \mathrm{O}_{2}\right)$ levels (Fig. 6A), (2) fluorometric estimation of the amount of reduced glutathione (GSH; Fig. 6B), (3) detection of AL-PCD by fluorescent visualization of cell nuclei containing free $3^{\prime}-\mathrm{OH}$ DNA strand breaks using TUNEL assay (Fig. 6C), and (4) DNA electrophoresis for the separation of different-sized DNA fragments (Fig. 6D).

Hydrogen peroxide $\left(\mathrm{H}_{2} \mathrm{O}_{2}\right)$, one of the key reactive oxygen species (ROS), has a major first-line defense role under various biotic and abiotic stress conditions in plants. 3,3'-diaminobenzidine tetrachloride (DAB), which in the presence of peroxidase is converted into polymerized reddish-brown deposits (Thordal-Christensen et al. 1997), and was used to evaluate the $\mathrm{H}_{2} \mathrm{O}_{2}$ level in both control (Fig. 6Aa) and 5-AU-treated root meristem cells (Fig. 6Ac). The specificity of the reaction has been proved by incubating seedlings in $1 \mathrm{mM}$ ascorbic acid ( $\mathrm{AA} ; \mathrm{H}_{2} \mathrm{O}_{2}$ scavenger; (Fig. 6Ab). Microcolorimetric analysis revealed that after treatment with 5-AU, the mean intracellular level of $\mathrm{H}_{2} \mathrm{O}_{2}$ was significantly higher (about fourfold, at $p<0.002$ ) than that observed in the control RAM cells (Fig. 6Ad).

The tripeptide thiol glutathione $(\gamma$-L-glutamyl-Lcysteinyl-glycine; GSH) is a powerful antioxidant and redox buffer involved in the detoxification of reactive oxygen species (ROS). The intracellular level of GSH was measured in the control (Fig. 6Ba-c) and 5-AU-treated root meristem cells (Fig. 6Bd-f) using glutathione detection reagent (ThiolTracker ${ }^{\mathrm{TM}}$ Violet), which reacts actively with reduced thiols groups in intact live cells. Although blue fluorescence staining appeared in both experimental variants, quantitative analysis clearly demonstrated that long-term exposure to low concentrations of 5-AU resulted in a statistically significant decrease $(p<0.001)$ in GSH level (Fig. 6g).

In order to evaluate the extent of DNA fragmentation, the agarose gel electrophoresis was used (Fig. 6C). When 

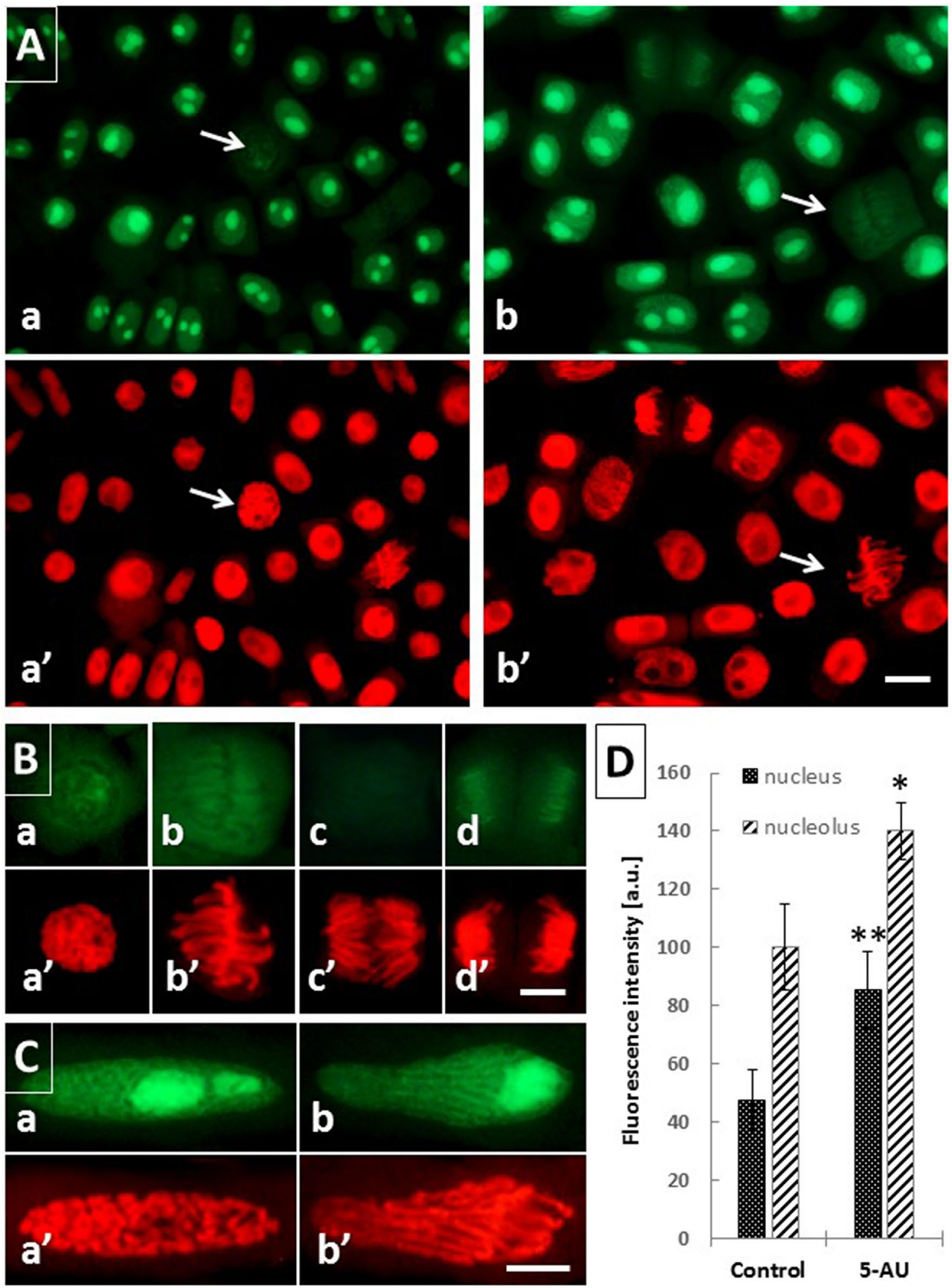

compared with the control (lane 2), a slightly increased mobility of relatively small DNA fragments extracted from 5-AU-treated RAM cells (lane 3 ) was observed.

The TUNEL assay (terminal deoxynucleotidyl transferase (TdT)-mediated dUTP nick-end labeling) combined with
DAPI staining was used to detect cell nuclei containing free 3'-OH DNA strand breaks (Fig. 6D). Fluorescent-labeled nuclei were found in almost all cells treated with DNase I (positive control; Fig. 6Da, a). In contrast to untreated (control) onion RAMs, where only a small population of 
४Fig. 4 Analysis of nascent transcription level in A. cepa RAM cells using EU incorporation followed by Click-iT ${ }^{\circledR}$ RNA Alexa Fluor ${ }^{\circledR}$ 488 imaging. A Detection of RNA synthesis in the control root tip cells (a) and after $72 \mathrm{~h} \mathrm{5-AU}$ treatment (b); corresponding images of the same cells counterstained with PI (a and $\mathbf{b})$; note faint fluorescence signal emitted in prophase (a, a; arrows) and metaphase cells (b, b; arrows). Scale bar $=20 \mu \mathrm{m}$. B Changes in nascent transcription level during successive stages of mitosis in the control onion cells at prophase (a), metaphase (b), anaphase (c), and telophase (d), with corresponding images of the same cells counterstained with PI (a-d, respectively). Scale bar $=10 \mu \mathrm{m}$. C Increased EU incorporation into nascent transcripts observed in elongated prophase (a) and the biphasic IM cells after $72 \mathrm{~h}$ treatment with 5-AU (b); corresponding images of the same cells counterstained with PI (a, b, respectively). Scale bar $=20 \mu \mathrm{m}$. D Microfluorimetric evaluation of mean nascent transcription levels measured for the nucleus and nucleolus in the control and 5-AU-treated onion RAM cells. When compared with the control, statistically significant changes in mean fluorescence levels $( \pm \mathrm{SD})$ expressed in arbitrary units [a.u.] are marked by asterisks: * indicates $p<0.05$ and $* *$ indicates 0.005

TUNEL-positive cells could be seen (about $0.5 \%$; Fig. $6 \mathrm{Db}$, b), after the 72-h treatment with 5-AU, the fluorescence signals were noted in about $10 \%$ of root meristem cells (Fig. 6Dc, c, Dd).

\section{Discussion}

Chromatin organization and cell cycle progression are tightly interconnected, and a vast number of different conditions must be met at particular time intervals prior to and during mitosis in order to complete nuclear division. The wide-ranging changes of the nucleoplasm that occur throughout the cell cycle create two structural conformations, one adapted to transcribe and to faithfully replicate genomic sequences during interphase, and the other adjusted to distribute chromosomes into daughter cells at mitosis (Morales et al. 2001; Raynaud et al. 2014; Żabka et al. 2010,2012). Both periods are commonly viewed as a continuous array of discrete stages, where each must be finished completely before the next one is allowed to start. To achieve this, the chronological sequence of metabolic events and successive step-to-step transitions is strictly monitored by signaling pathways known as the cell-cycle checkpoints (Hartwell and Weinert 1989).

Evidence from our previous studies (Żabka et al. 2010, 2012, 2013, 2015a, b) indicated that continuous treatment of onion RAMs with a low concentration of HU may disrupt crucial functions of the checkpoint response system, leading cells to abnormal mitotic progression manifested by premature chromosome condensation (PCC phenotype) and by axially elongated cells with half interphase/half mitotic structures (IM phenotype having both dispersed and condensed domains of chromatin). Our current work shows that prolonged incubations of 4-day-old primary roots of $A$. серa with many chemical agents (including those commonly used to inhibit DNA replication) can induce interphase-mitotic organization of nuclear chromatin structures. Among all agents tested at nontoxic concentrations, 5-AU was found to be the most effective with regard to generating PCC and
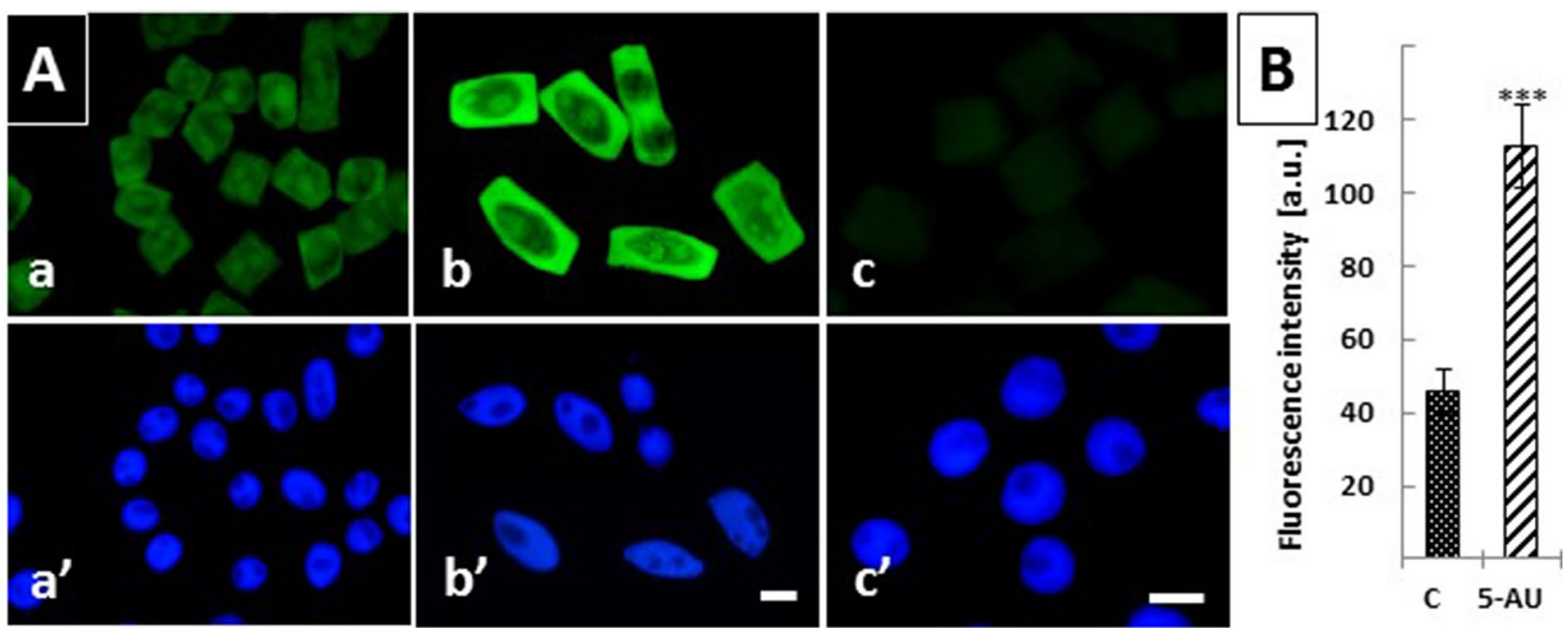

Fig. 5 Nascent protein synthesis detected using Click-iT® HPG Alexa Fluor ${ }^{\circledR} 488$ imaging in A. cepa RAM cells. (A) Immunofluorescence of proteins: control (a), $72 \mathrm{~h}$ treatment with 5-AU (b), negative control series performed using $(50 \mu \mathrm{M})$ cycloheximide (c); corresponding images of the same cells counterstained with DAPI $\left(a^{\prime}-c^{\prime}\right)$. Scale bars $=20 \mu \mathrm{m}$. (B) Microfluorimetric evaluation of pro- tein synthesis levels (Fluorescence intensity [a.u.]) expressed in arbitrary units, calculated as mean pixel value $( \pm S D)$ measured at the cytoplasm area. When compared with the control, the fluorescence intensity in 5-AU-treated is increased, with the statistical significance at $p<0.001$ 

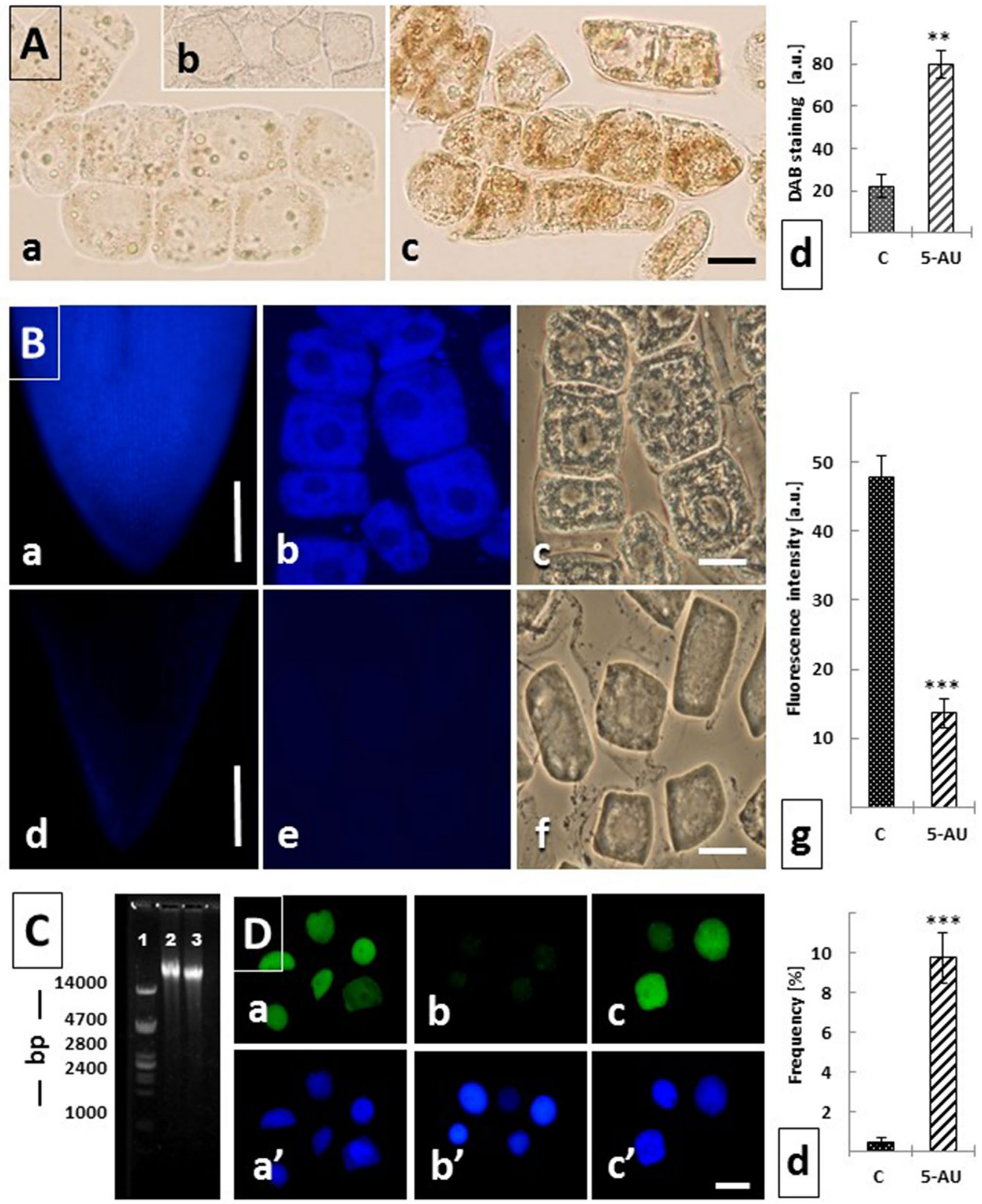

IM cells (with its effectiveness only slightly lower than that of $\mathrm{HU})$.

There seems to be an evident discrepancy between the general phenotypic response of onion seedlings to 照 Springer
5-AU-induced stress conditions (applied at low concentration), manifested by the gradual reduction of root meristem size (observed also in all other experimental series), and the increased biochemical activities involved in DNA 
४Fig. 6 Generation of ROS, changes in GSH levels, DNA fragmentation, and induction of AL-PCD in A. cepa RAM cells following prolonged $(72 \mathrm{~h})$ treatment with 5-AU. (A) DAB-stained cells in the control root meristem (a), in root cells after $72 \mathrm{~h}$ treatment with the mixture containing 5-AU and $1 \mathrm{mM}$ ascorbic acid (b), and in root cells incubated for $72 \mathrm{~h}$ with 5 -AU (c). Scale bar $=20 \mu \mathrm{m}$. Cytometric evaluation of the DAB staining intensities in the control $(\mathbf{C})$ and 5-AU-treated RAM cells ([a.u.]—arbitrary units); statistical significance at $p<0.001$. (B) Detection of reduced glutathione (GSH) using ThiolTracker ${ }^{\mathrm{TM}}$ Violet fluorescence assay: longitudinal thick section of onion root meristems from the control $(\mathbf{a}-\mathbf{c})$ and 5-AU-treated seedlings (d-f); individual RAM cells at large magnification: control (b), 5-AU treatment (e), and the same cells viewed under phase contrast (c, f, respectively); scale bars $=500 \mu \mathrm{m}$ for a and d, and $20 \mu \mathrm{m}$ for (b, c, e, and f). Microfluorimetric evaluation ([a.u.- arbitrary units) of the mean total GSH fluorescence $( \pm S D$; g) in the control (C) and 5-AU-treated RAM cells, with the statistical significance at $p<0.001$. C Agarose gel electrophoresis assay for DNA extracted and purified from onion root meristem cells: lane 1 -mass marker, lane 2-control, and lane 3-5-AU treatment for $72 \mathrm{~h}$. Note some shift of DNA towards lower buoyant density due to DNA fragmentation after incubations with 5-AU. D Detection of AL-PCD by TUNEL assay in DNase I-treated RAM cells (positive control; a), in the untreated control root cells (b), and in root meristem cells exposed to $72 \mathrm{~h}$ treatment with 5-AU (c); the same cells are visualized after DAPI staining $(\mathbf{a}-\mathbf{c})$, scale bar $=20 \mu \mathrm{m}$; mean frequency [\%] of TUNEL-positive RAM cells in the control $(\mathbf{C})$ and 5-AU-treated onion meristems; statistical significance at $p<0.001(\mathbf{d})$

replication, transcription and translation. At present, it would be difficult to explain these conflicting results other than by assuming that-under the influence of harmful chemical substances or unfavorable environmental factors - certain plant-specific "problem-solving mechanisms" are organized and dynamically displayed to establish functionally effective and operationally efficient metabolic facilities, which help support the continued growth and differentiation of root cells and tissues.

In agreement with our earlier studies, both onion RAM cells with apparent symptoms of premature chromosome condensation (PCC-like cells), as well as those showing unusual biphasic IM nuclear structures should be considered as the ultimate consequence of three consecutive physiological events, taking place right from the start of the drug treatment: (1) an inhibitory stage induced directly by the DNA damage and the impaired DNA synthesis, (2) an adaptation stage comprising means to activate a complicated network of DNA damage response (DDR) mechanisms, and (3) a recovery stage, during which early symptoms diminish and some cells restore their lost functions despite the continued presence of the stress factor (Źabka et al. 2010, 2012, 2015a, b). As a consequence, the first observed effect of low-dose HU treatment in onion RAMs consisted in a decreased frequency of nuclear divisions, followed by a period of constant cell enlargement, which, in turn was succeeded by a renewed rise in mitotic activity, giving rise to various forms of mitosis, including PCC-like and IM cells. However, irrespective of this, what stands out as a common final outcome of all drug treatments, it seems like there is some kind of correspondence between the time-dependent effects observed in former experiments (confined to HU-generated DNA damage) and the succession of 5-AU-induced changes at the DNA replication level. Accordingly, our present results obtained using fluorescence EdU assays clearly indicate that, within the first $3 \mathrm{~h}$ of onion root treatment with 5-AU, the intensity of nuclear DNA labeling decreases (corresponding to the inhibitory stage), then, it increases continuously during the next several hours of incubation (adaptation stage), and afterwards, it attains the maximum values (2.6-fold higher than the minimum) at the 48-72 $\mathrm{h}$ time points (recovery stage). In fact, a similar timeline of changes, although not exactly matching, was obtained for EdU labeling indices, with their highest value recorded in A. cepa RAM cell populations as soon as after $12 \mathrm{~h}$ of treatment. The prolonged and partially overlapping periods of the enhanced intensity of EdU labeling and of the increased EdU labeling index suggest a largescale reprogramming of DNA replication patterns, probably reflecting changes in origin concentration, in their efficiency, and in relative duration of DNA synthesis. Resolving these problems may come from a more precise characterization of the replicons using molecular combing of EdU-labeled DNA fibers, which seems feasible considering strong fluorescence signals obtained in our present simplified version of DNA extraction and spreading assay. Thus, it is probable that cell cycle checkpoints activation by low concentration of 5-AU causes additional firing of replication origins, modifications of DNA replication-associated proteins (De Piccoli et al. 2012), upregulation of dNTP pools (Jossen and Bermejo 2013), as well as relaxation of chromosome architecture to relieve topological stress (Bermejo et al. 2011).

It is well-known that collisions between RFs and transcription bubbles give rise to the formation of stable RNA:DNA hybrids (triple stranded structures termed R-loops), which slow-down or arrest DNA replication, induce premature termination of transcription, and generate DNA replication stress (Brambati et al. 2015; Gaillard et al. 2015; García-Muse and Aguilera 2016). Accordingly, spatial and temporal separation of replication and transcription can reduce the number of such conflicts, without preventing them completely, especially in large, transcriptionally active genes, characterized by an enhanced sensitivity to RS (Helmrich et al. 2011). Furthermore, a number of studies have shown that replication inhibitors can induce collisions between the transcription machinery and RFs, and affect the dynamics of transcription (Hamperl et al. 2017). It was hypothesized that the appearance of double-stranded breaks (DSBs) results in conflicts between replication and increased transcription at HU-induced genes (Hoffman et al. 2015). Hosseini et al. (2016) revealed that HU elicits a significant effect on the transcriptome of the murine embryos, where the expression of 1346 transcripts was significantly changed 
(at least 1.5-fold) in HU-treated embryos, when compared with the control group.

Although, as in the case of HU, the side effects of numerous forms of DNA damage reported in the present study result in a considerable decrease in RAM size, the response of root tip cells exposed to 5-AU is associated, paradoxically, with significantly increased activation of the transcriptional and translational expression levels. When considering the data from our experiments with EdU as a thymidine analog and the results obtained using 5-ethynyl uridine (5-EU) transcription assay, it is obvious that both DNA replication and transcription may perform their specific tasks efficiently and simultaneously using common DNA templates without mutual interference. Thus, irrespective of DNA mismatches formed by 5-AU located as a middle base of a triplex triad via Hoogsteen hydrogen bonds (Rana and Ganesh 2000; Shaker et al. 2016), the replication and transcription processes must have retained their ability to perform essential functions in a highly coordinated manner, preventing potential conflicts, which are the main intrinsic source of genome instability (Helmrich et al. 2011; García-Muse and Aguilera 2016). Correspondingly, it cannot be ruled out that the cellular response to 5-AU-induced RS includes rapid transcriptional activation of genes involved in DNA metabolism and in the mechanisms engaged in DNA damage repair systems.

Apart from the direct influence of 5-AU (and of other inhibitors of DNA synthesis) as the main source of DNA replication stress, there may be also an indirect influence, or multiplier effect, resulting from interactions between DNA and ROS, which are known to play a dual role of regulatory and toxic factors (Jajic et al. 2015; Mittler 2017). The oxidative stress results in a wide array of physiological and biochemical reactions, comprising disturbances in water balance, membrane injuries, reduced protein synthesis, changes in gene expression, alterations in the dynamics of metabolism and phytohormone levels (Gill and Tuteja 2010; Bita and Gerats 2013). If the state of stress lasts too long (or becomes intensified), it may lead to cellular disorders, tissue dysfunctions, and even to the death of the plant (Potters et al. 2009). Although the excess of free radicals, such as hydrogen peroxide $\left(\mathrm{H}_{2} \mathrm{O}_{2}\right)$, hydroxyl radical $(\mathrm{OH})$, or superoxide anion $\left(\mathrm{O}_{2}{ }^{--}\right.$; Sharma et al. 2012; Demidchik 2015) can damage a variety of specific components within the genome, still little is known about the molecular mechanisms that protect DNA from oxidative stress. The attack of ROS on DNA results both in hydrogen abstraction from 2-deoxyribose (damaged sugar residues) and in addition of ${ }^{\bullet} \mathrm{OH}$ to the terminal carbon of the double bond (altered bases; Roldan-Arjona and Ariza 2009; Sharma et al. 2012). A link between inhibitors of replication and oxidative stress has been observed in several species, including HU-treated RAM cells in Arabidopsis thaliana (Yi et al. 2014) and endothelial cells with APH (Schilder et al. 2009).
The stress conditions in 5-AU-treated A. cepa RAM cells brought about a significant increase in the $\mathrm{H}_{2} \mathrm{O}_{2}$ concentration, which was evidenced using chromogenic DAB substrate. Similar effects, associated with the enhanced production of $\mathrm{H}_{2} \mathrm{O}_{2}$, have been observed in onion roots incubated with HU (Żabka et al. 2012), $\beta$-lapachone (Żabka et al. 2013) and sanguinarine (Żabka et al. 2017). Because $\mathrm{H}_{2} \mathrm{O}_{2}$ generates SSB, DSB (Żabka et al. 2013), and induce transcriptional activation of DNA stress genes, such as PARP2 and BRCA1 (Vanderauwera et al. 2011), it seems probable that aberrant chromatin morphology, formation of micronuclei, and induction of AL-PCD, are not only a consequence of a direct inhibitory influence of 5-AU, but also the effect of $\mathrm{H}_{2} \mathrm{O}_{2}$ (and other forms of ROS) generated as a secondary by-product induced by 5 -AU. In consequence, the time-dependent activation of DNA damage response pathways and the ensuing resistance to stress conditions, accompanied by almost unchanged electrophoretic mobility of DNA, and a relatively small number of AL-PCD events may partially depend on a rapid increase in endogenous antioxidants levels. As evidenced, the stress-relief program of 5-AU-treated onion RAM cells is associated with a significant reduction in the intracellular level of the reduced glutathione (GSH), the dominant multifunctional thiol metabolite that plays a key role in plant growth and development and acts as the main ROS scavenger within plant cells during abiotic and biotic stress conditions (Zechmann 2014).

The data and observations reported in previous studies have shown that mild replication stress is correlated with: (1) an enhanced phosphorylation of H2AX histones (increase in number of $\gamma$-H2AX foci, which help recruit intra-S-phase checkpoint proteins and promote mechanisms of DNA repair), (2) changes in the progression of the S- and G2-phases, and (3) a gradual accumulation of cyclin B-like (CBL) proteins (Żabka et al. 2012). The asymmetrical accumulation of CBL proteins was implicated as a crucial factor responsible for the polarized activation of CDKs, and consequently, as a direct cause of an abnormal (IM) passage through the nuclear division. During this process, the onset of chromatin condensation is initiated in the vicinity of the pericentric regions, which was supported by the immunolocalization of phosphorylated $\mathrm{H} 3$ histones $(\mathrm{H} 3 \mathrm{~S} 10 \mathrm{Ph})$ at the most condensed segments of the emergent chromosomes (Żabka et al. 2010, 2012). Other prerequisites needed to facilitate the formation of IM cells were found to consist in: (1) a distinct separation of centromeric and telomeric domains of the interphase nucleus (known as Rabl configuration, which appears to be a consequence of the chromatin polarity acquired during mitotic division), (2) a parallel alignment of chromatin domains and the base $\rightarrow$ apex orientation of 
the RAM cell files, and (3) a specific association between the advanced mitotic (M)-poles of the IM cell nuclei and the polarized accumulation sites of PIN2 auxin efflux carriers and IAA (Żabka et al. 2015a). Our present experiments supplement the existing list of cellular conditions indispensable for the formation of both types of aberrant M-phase cells (having PCC-like or IM phenotypes) by including the enhanced transcription and translation levels, which allow for sustained nuclear functions and persistent cell growth. At the same time, they pose new problems for future research, concerning the mechanism by which stress conditions accelerate the dynamics of the DNA replication machinery.

Author contribution statement AŻ planned, carried out the experiments and prepared the raw version of the article, JP, KW, and JB-S equally contributed to acquisition of the results and performed most of the data analyses including statistics, JM participated in the conception and design of the study and prepared the final version of the manuscript.

\section{Compliance with ethical standards}

Conflict of interest The authors declare that they have no conflict of interest.

Open Access This article is licensed under a Creative Commons Attribution 4.0 International License, which permits use, sharing, adaptation, distribution and reproduction in any medium or format, as long as you give appropriate credit to the original author(s) and the source, provide a link to the Creative Commons licence, and indicate if changes were made. The images or other third party material in this article are included in the article's Creative Commons licence, unless indicated otherwise in a credit line to the material. If material is not included in the article's Creative Commons licence and your intended use is not permitted by statutory regulation or exceeds the permitted use, you will need to obtain permission directly from the copyright holder. To view a copy of this licence, visit http://creativecommons.org/licenses/by/4.0/.

\section{References}

Anderson EN, Corkins ME, Li JC, Singh K, Parsons S, Tucey TM, Sorkaç A, Huang H, Dimitriadi M, Sinclair DA, Hart AC (2016) C. elegans lifespan extension by osmotic stress requires FUdR, base excision repair, FOXO, and sirtuins. Mech Ageing Dev 154:30-42

Bermejo R, Capra T, Jossen R, Colosio A, Frattini C, Carotenuto W, Cocito A, Doksani Y, Klein H, Gómez-González B, Aguilera A, Katou Y, Shirahige K, Foiani M (2011) The replication checkpoint protects fork stability by releasing transcribed genes from nuclear pores. Cell 146:233-246

Berti M, Vindigni A (2016) Replication stress: getting back on track. Nat Struct Mol Biol 23:103-109

Bita CE, Gerats T (2013) Plant tolerance to high temperature in a changing environment: scientific fundamentals and production of heat stress-tolerant crops. Front Plant Sci 4:273

Brambati A, Colosio A, Zardoni L, Galanti L, Liberi G (2015) Replication and transcription on a collision course: eukaryotic regulation mechanisms and implications for DNA stability. Front Genet 6:166

Choudhury FK, Rivero RM, Blumwald E, Mittler R (2017) Reactive oxygen species, abiotic stress and stress combination. Plant $\mathbf{J}$ 90:856-867

Cools T, Iantcheva A, Weimer AK, Boens S, Takahashi N, Maes S, Van den Daele H, Van Isterdael G, Schnittger A, De Veylder L (2011) The Arabidopsis thaliana checkpoint kinase WEE1 protects against premature vascular differentiation during replication stress. Plant Cell 23:1435-1448

Cutolo M, Sulli A, Pizzorni C, Seriolo B, Straub RH (2001) Antiinflammatory mechanisms of methotrexate in rheumatoid arthritis. Ann Rheum Dis 60:729-735

De Piccoli G, Katou Y, Itoh T, Nakato R, Shirahige K, Labib K (2012) Replisome stability at defective DNA replication forks is independent of S phase checkpoint kinases. Mol Cell 45:696-704

Demidchik V (2015) Mechanisms of oxidative stress in plants: from classical chemistry to cell biology. Environ Exp Bot 109:212-228

Eykelenboom JK, Harte EC, Canavan L, Pastor-Peidro A, Calvo-Asensio I, Llorens-Agost M, Lowndes NF (2013) ATR activates the S-M checkpoint during unperturbed growth to ensure sufficient replication prior to mitotic onset. Cell Rep 5:1095-1107

Franco JA, Bañón S, Vicente MJ, Miralles J, Martínez-Sánchez JJ (2011) Root development in horticultural plants grown under abiotic stress conditions-a review. J Hortic Sci Biotechnol 86:543-556

Gaillard H, Garcia-Muse T, Aguilera A (2015) Replication stress and cancer. Nat Rev Cancer 15:276-289

García-Muse T, Aguilera A (2016) Transcription-replication conflicts: how they occur and how they are resolved. Nat Rev Mol Cell Biol 17:553-563

Gelot C, Magdalou I, Lopez BS (2015) Replication stress in mammalian cells and its consequences for mitosis. Genes (Basel) 6:267-298

Giglia-Mari G, Zotter A, Vermeulen W (2011) DNA damage response. Cold Spring Harb Perspect Biol 3:a000745

Gill SS, Tuteja N (2010) Reactive oxygen species and antioxidant machinery in abiotic stress tolerance in crop plants. Plant Physiol Biochem 48:909-930

Hamperl S, Bocek MJ, Saldivar JC, Swigut T, Cimprich KA (2017) Transcription-replication conflict orientation modulates R-loop levels and activates distinct DNA damage responses. Cell 170:774-786

Hartwell LH, Weinert TA (1989) Checkpoints: controls that ensure the order of cell cycle events. Science 246:629-634

Helmrich A, Ballarino M, Tora L (2011) Collisions between replication and transcription complexes cause common fragile site instability at the longest human genes. Mol Cell 44:966-977

Hoffman EA, McCulley A, Haarer B, Arnak R, Feng W (2015) Breakseq reveals hydroxyurea-induced chromosome fragility as a result of unscheduled conflict between DNA replication and transcription. Genome Res 25:402-412

Hosseini P, Abidi SZ, Du E, Papageorgiou DP, Choi Y, Park Y, Higgins JM, Kato GJ, Suresh S, Dao M, Yaqoob Z, So PT (2016) Cellular normoxic biophysical markers of hydroxyurea treatment in sickle cell disease. Proc Natl Acad Sci USA 113:9527-9532

Jajic I, Sarna T, Strzalka K (2015) Senescence, stress, and reactive oxygen species. Plants (Basel) 4:393-411

Jossen R, Bermejo R (2013) The DNA damage checkpoint response to replication stress: a game of forks. Front Genet 4:26

Labit H, Goldar A, Guilbaud G, Douarche C, Hyrien O, Marheineke $\mathrm{K}$ (2008) A simple and optimized method of producing silanized surfaces for FISH and replication mapping on combed DNA fibers. Biotechniques 45:649-652 
Magdalou I, Lopez BS, Pasero P, Lambert SA (2014) The causes of replication stress and their consequences on genome stability and cell fate. Semin Cell Dev Biol 30:154-164

Mazouzi A, Velimezi G, Loizou JI (2014) DNA replication stress: causes, resolution and disease. Exp Cell Res 329:85-93

Mittler R (2017) ROS are good. Trends Plant Sci 22:11-19

Morales V, Giamarchi C, Chailleux C, Moroa F, Marsaudd V, Le Ricoussee S, Richard-Foya H (2001) Chromatin structure and dynamics: functional implications. Biochimie 83:1029-1039

Polit JT, Maszewski J, Kaźmierczak A (2002) Effect of BAP and IAA on the expression of G1 and G2 control points and the G1-S and G2-M transitions in root meristem cells of Vicia faba. Cell Biol Int 27:559-566

Potters G, Pasternak TP, Guisez Y, Jansen MAK (2009) Different stresses, similar morphogenic responses: integrating a plethora of pathways. Plant Cell Environ 32:158-169

Rana VS, Ganesh KN (2000) Recognition of 5-aminouracil (U(\#)) in the central strand of a DNA triplex: orientation selective binding of different third strand bases. Nucleic Acids Res 28:1162-1169

Raynaud C, Mallory A, Latrasse D, Jegu T, Bruggeman Q, Delarue M, Bergounioux C, Benhamed M (2014) Chromatin meets cell cycle. J Exp Bot 65:2677-2689

Roldan-Arjona T, Ariza RR (2009) Repair and tolerance of oxidative DNA damage in plants. Mutat Res 681:169-179

Saban N, Bujak M (2009) Hydroxyurea and hydroxamic acid derivatives as antitumor drugs. Cancer Chemother Pharmacol 64:213-221

Schilder YD, Heiss EH, Schachner D, Ziegler J, Reznicek G, Sorescu D, Dirsch VM (2009) NADPH oxidases 1 and 4 mediate cellular senescence induced by resveratrol in human endothelial cells. Free Radic Biol Med 46:1598-1606

Segurado M, Tercero JA (2009) The S-phase checkpoint: targeting the replication fork. Biol Cell 101:617-627

Shaker RM, Elrady MA, Sadek KU (2016) Synthesis, reactivity, and biological activity of 5-aminouracil and its derivatives. Mol Divers 20:153-183

Sharma P, Jha AB, Dubey RS, Pessarakli M (2012) Reactive oxygen species, oxidative damage, and antioxidative defense mechanism in plants under stressful conditions. J Bot 2012:217037

Stauffer D, Chang B, Huang J, Dunn A, Thayer M (2007) p300/CREBbinding protein interacts with ATR and is required for the DNA replication checkpoint. J Biol Chem 282:9678-9687

Thordal-Christensen H, Zhang Z, Wei Y, Collinge DB (1997) Subcellular localization of $\mathrm{H}_{2} \mathrm{O}_{2}$ in plants. $\mathrm{H}_{2} \mathrm{O}_{2}$ accumulation in papillae and hypersensitive response during the barley-powdery mildew interaction. Plant J 11:1187-1194

Van't Hof J (1980) Pea (Pisum sativum) cells arrested in G2 have nascent DNA with breaks between replicons and replication clusters. Exp Cell Res 129:231-237

Vanderauwera S, Suzuki N, Miller G, van de Cotte B, Morsa S, Ravanat J-L, Hegie A, Triantaphylidès C, Shulaev V, Van Montagu MCE, Van Breusegem F, Mittler R (2011) Extranuclear protection of chromosomal DNA from oxidative stress. Proc Natl Acad Sci USA 108:1711-1716
Wang P, Ownby S, Zhang ZZ, Yuan W, Li SY (2010) Cytotoxicity and inhibition of DNA topoisomerase I of polyhydroxylated triterpenoids and triterpenoid glycosides. Bioorg Med Chem Lett 20:2790-2796

Waterworth WM, Drury GE, Bray CM, West CE (2011) Repairing breaks in the plant genome: the importance of keeping it together. New Phytol 192:805-822

Yi D, Alvim Kamei CL, Cools T, Vanderauwera S, Takahashi N, Okushima Y, Eekhout T, Yoshiyama KO, Larkin J, Van den Daele H, Conklin P, Britt A, Umeda M, De Veylder L (2014) The Arabidopsis SIAMESE-RELATED cyclin-dependent kinase inhibitors SMR5 and SMR7 regulate the DNA damage checkpoint in response to reactive oxygen species. Plant Cell 26:296-309

Yokoyama R, Hirakawa T, Hayashi S, Sakamoto T, Matsunaga S (2016) Dynamics of plant DNA replication based on PCNA visualization. Sci Rep 6:29657

Zechmann B (2014) Compartment-specific importance of glutathione during abiotic and biotic stress. Front Plant Sci 5:566

Zeman MK, Cimprich KA (2014) Causes and consequences of replication stress. Nat Cell Biol 16:2-9

Żabka A, Polit JT, Maszewski J (2010) Inter- and intrachromosomal asynchrony of cell division cycle events in root meristem cells of Allium cepa: possible connection with gradient of cyclin B-like proteins. Plant Cell Rep 29:845-856

Żabka A, Polit JT, Maszewski J (2012) DNA replication stress induces deregulation of the cell cycle events in root meristems of Allium cepa. Ann Bot 110:1581-1591

Żabka A, Trzaskoma P, Maszewski J (2013) Dissimilar effects of $\beta$-lapachone- and hydroxyurea-induced DNA replication stress in root meristem cells of Allium cepa. Plant Physiol Biochem 73:282-293

Żabka A, Trzaskoma P, Winnicki K, Polit JT, Chmielnicka A, Maszewski J (2015a) The biphasic interphase-mitotic polarity of cell nuclei induced under DNA replication stress seems to be correlated with Pin2 localization in root meristems of Allium cepa. J Plant Physiol 174:62-70

Żabka A, Winnicki K, Polit JT, Joanna Bernasińska J, Maszewski J (2015b) Localization sites of nuclear envelope SUN2-like proteins in root meristem cells of Allium cepa under hydroxyurea-induced DNA replication stress. Acta Physiol Plant 37:163

Żabka A, Polit JT, Winnicki K, Paciorek P, Juszczak J, Nowak M, Maszewski J (2016) PIN2-like proteins may contribute to the regulation of morphogenetic processes during spermatogenesis in Chara vulgaris. Plant Cell Rep 35:1655-1669

Żabka A, Winnicki K, Polit JT, Maszewski J (2017) Sanguinarineinduced oxidative stress and apoptosis-like programmed cell death (AL-PCD) in root meristem cells of Allium cepa. Plant Physiol Biochem 112:193-206

Publisher's Note Springer Nature remains neutral with regard to jurisdictional claims in published maps and institutional affiliations. 